\title{
Control the activity of Rift Valley Fever Virus by Electric Field waves at resonance frequency (In vivo \&In vitro) studies
}

\author{
Fadel $\mathrm{Ali}^{1}$, Hala Moustafa ${ }^{2}$, Nashwa Abbas ${ }^{3}$,Hanan Moustafa ${ }^{4}$, \\ Hamida Hamdi ${ }^{5}$ \\ Biophysics, Faculty of Science, Cairo University ${ }^{l}$, Medical Biophysics, Faculty of Applied Medical Science, \\ October Six University ${ }^{2}$, Microbiology, Faculty of Applied Medical Science, October Six University ${ }^{3}$, Narcotic \\ Department, National Center for Social and Criminological Research, Cairo, Egypt. ${ }^{4}$ Zoology department, \\ Faculty of Science, Cairo University
}

\begin{abstract}
Rift valley fever virus (RVFV) causes severe disease, abortion and deaths in domestic animals (especially) young sheep, cattle and goats humans are infected by this virus through mosquitoes which maintain epizootic transmission being in contact with infected animal tissue. For this purpose, RVFV activities in Vero cell line media were exposed to different frequencies of amplitude modulated (AM) waves in the frequency range ( from $1 \mathrm{~Hz}$ to $10 \mathrm{~Hz}$ ) for a period of 30 minutes /day along four successive days no measurable effect of the square amplitude modulated waves $(Q A M W)$ was noticed after the experiment in the Vero-cells. In another experiment 48 female Bulb/C mice were equally divided into 6 groups namely $A_{1}, A_{2}, A_{3}, A_{4}, A_{5}$ \& negative control. $A_{1}, A_{4} \& A_{5}$ animals were infected by injection intraperitoneal (i.p) with dose of $R V F V(0.15 \mathrm{mg} / \mathrm{Kg}$ body weight (b.w). $A_{4} \& A_{5}$ were exposed for 30 minutes /day along four successive days to $4.4 \mathrm{~Hz} \& 5.2 \mathrm{~Hz}$ respectively while $A_{1}$ without treatment any further treatment $A_{2} \& A_{3}$ animals were exposed to $4.4 \mathrm{~Hz} \& 5.2 \mathrm{~Hz}$ respectively for 30 minutes /day along four successive days, control group were injected $100 \mu l$ of saline by (i.p). At day 28 post injection of the animal, blood was collected for each group then after at sacrifice the liver enzymes (SGPT\&SGOT), cellular changes were evaluated using cytokines expression (IFN- $\gamma$ \& IL-5) the exposed and non exposed ELF were studied survival rate and histopathology were demonstrated. The results: In vitro the data highly significant growth enhancement \& inhibition respectively occurred in RVFV injected with vero cells after exposure to $4.4 \mathrm{~Hz} \& 5.2 \mathrm{~Hz}$ respectively $Q A M W$ for 30 minutes/day along four successive days. In vivo the groups $A_{1}, A_{2} \& A_{3}$ highly significant increase in the serum level of $S G P T \& S G O T$ by less than $A_{4} \& A_{5}$ groups respectively. The groups $A_{2} \& A_{3}$ were a significant increase in the serum level of IFN- $\gamma$. While, the serum level of IFN- $\gamma$ of groups $A_{1}, A_{4}$ and $A_{5}$ exhibited a significant decrease. Where the results were slightly increase but non-significant in level of $I L-5$ production in serum in groups $A_{2}$ and $A_{3}$. While the level of $I L-5$ of group $A_{1}$ were a highly significant suppression more than in the groups $A_{4} \& A_{5}$ when compared to control. Histological sections of the exposed and non exposed were studied and survival rate were demonstrated.

Key words: RVFV, Electromagnetic waves, Vero cells, square amplitude modulated waves (QAMW).
\end{abstract}

\section{Introduction}

Rift Valley fever (RVF) is a zoonotic arthropod-borne pathogen. It is a significant global threat and often results in severe morbidity and mortality in both humans and livestock. Historically, it was restricted to sub-Saharan Africa (Swanepoel and Coetzer, 2004).Rift Valley fever virus is recognized as an important bioterror and agroterror threat to Western countries including the United States. Once introduced, the virus would be readily spread by native mosquito populations and potentially become endemic. While infection often results in severe morbidity and mortality in both humans and livestock, there are currently no FDA or USDAlicensed vaccines Rebekah Kading, Mary Crabtree, Barry Miller. (2013).Recent studies illustrated the ability of RVFV to utilize the dominant mosquito species of a given geographical location, which indicates that there is no natural blockade to protect naive countries from the spread of the virus. This presents a real threat for RVFV incursions into other parts of the world (Moutailler et al., 2008; Turell et al., 2008). However, differences in RVFV transmission rates can be affected by local mosquito populations (Turell et al., 2010). No highly effective RVFV specific therapeutics currently exists with the exception of ribavirin as an approved drug (Bouloy et al., 2009). A few compounds are licensed as approved antiviral drugs for the hemorrhagic fever viruses. However, the effectiveness of ribavirin is limited due to its side effect complications and lack of specificity (Gowen and Holbrook, 2008;Kortekaas, et al. .,2012).

Electromagnetic radiation (EMR) is a form of energy emitted and absorbed by charged particles, which exhibits wave-like behavior as it travels through space. EMR has both electric and magnetic field components, which oscillate in phase perpendicular to each other and perpendicular to the direction of energy and propagation. The effects of extremely low-frequency (ELF) electromagnetic fields on biological systems have been reported by various workers (Saunders et al 1991, Mittenzweya et al 1996). Among several studies 
of the last years, bacteria were subjected to many experimental procedures to evaluate how such unicellular systems may respond to EMFs (Pothakamury et al., 1996; Jeantet et al., 1999; Fojt et al., 2004; Amiali et al., 2007; Jaegu et al., 2008; Ji et al., 2009; Tagourti et al., 2010). However, most of this experimental works used electromagnetic fields of high field intensity in the range from $10 \mathrm{KV} / \mathrm{cm}$ up to several $\mathrm{mV} / \mathrm{m}$ (Cserhalmi et al., 2002; Fleischman et al., 2004; Fox et al., 2008; Ruiz-Gomez et al., 2010) with the aid of very high temperature for inactivation of bacterial growth. Under these experimental conditions, it became so difficult to apply this technique in practice either for the treatment of human infections or pasteurization and sterilization of food products. Recently, the efforts were devoted to control cellular activities by using electromagnetic waves of very low field intensity and frequencies which resonates with bioelectric signals generated during a particular metabolic activity. By this model succeeded to control the growth of Ehrich tumors in mice (Fadel et al., 2005), bacterial cells (Fadel $\boldsymbol{e t}$ al, 2012) and fungi (Fadel $\boldsymbol{e t}$ al., 2009). A variety of theoretical models have been suggested to describe the interaction mechanisms of ELF-EMFs with biological systems such as Ion Cyclotron Resonance (ICR) model (Liboff et al., 1987; Lednev, 1991) and Ion Parametric Resonance (IPR) model by (Blanchard et al., 1994). However, none of these models succeeded to explain with enough confidence and all biological changes following exposures to these electromagnetic waves. Later on, (Fadel, 1998) suggested the Metabolic Biomagnetic Resonance (MBMR) model to explain the interaction mechanisms of ELF-EMFs at resonance frequencies with physiological processes.

The main objective of this work is to find the resonance frequency of (ELF-EMFs) the control viral cell growth where the resonance of the extremely high and low frequency electromagnetic fields (ELF-EMFs) that can enhance and inhibit the activity of RVFV in mice and its ability to make activity of the virus. Moreover, Biochemical examination were determined by evaluating various cellular activities (SGPT\&SGOT) and level cytokines production (IFN- $\gamma$ and IL-5) in serum and histopathological findings that may occur as a result of exposure to the enhancement and inhibiting resonance frequency of the ELF-EMFs .

\section{[ A ] In vitro studies:}

\section{Materials And Methods}

\section{1- Preparation of (RVFV) strain and Vero Cells:}

RVFV pan tropic Menya Strain (Menya/Sheep/258) and the Vero cell line were kindly obtained from VACSERA, Egypt.

Vero cells (isolated from kidney epithelial cells of an African green monkey (Cercopithecus aethiops) were maintained in 199 medium (Invitrogen, Carlsbad, CA) containing 10\% fetal bovine serum. For the preparation of the Vero cells stock the growth medium was removed from the cell culture flasks and the monolayer was washed with sterile PBS, $\mathrm{pH}$ 7.2. Vero cells were trypsinized by adding $10 \mathrm{ml}$ of trypsin solution $(0.25 \%$ W/V trypsin - EDTA solution (Invitrogen, San Diego, Calif. USA) to the monolayer and left in contact with cells for 15-30 seconds, the solution was removed and the culture held at $37{ }^{\circ} \mathrm{C}$ until the cells had pulled apart. The cells were suspended to the proper concentration of $\left(2 \times 10^{5}\right.$ cell $\left./ \mathrm{ml}\right)$ in $25 \mathrm{~cm}^{2}$ tissue culture flasks (Nunc, Roskilde, Denmark) using 199 medium (GIBCO) supplemented with 200 mMl-glutamine, 10\% fetal calf serum (Sigma Chemical Co., St Louis, MO, USA), $100 \mathrm{IU} / \mathrm{ml}$ penicillin and $100 \mathrm{mg} / \mathrm{ml}$ streptomycin, incubation was carried out at $37^{\circ} \mathrm{C}$ in moist atmosphere containing $5.2 \% \mathrm{CO}_{2}$ incubator. Bottles were shacked for $15 \mathrm{~min}$ for the assurance of the well viral distribution. After the formation of the monolayer complete sheet, $100 \mathrm{ml}$ of maintenance media were added to each bottle. Inoculated bottles were daily microscopically observed for 7 days for detection of cellular changes and development of cytopathic effect (CPE). Flasks developed CPE were freezed and thawed three times for virus extraction. (Bussereau et al., 1982).

\section{2- In vitro Toxicity:}

Cytotoxicity assay of liquorice powder extract and acyclovir (Galaxo Smithkline-Italy) was determined according to Finter (1990) and Vijayan (2004), where sterile filtrated liquorices and acyclovir extracts were diluted in MEM-E to prepare $2 \mathrm{mg} / \mathrm{ml}$ final concentration. Negative cell culture control was considered. The plates were incubated at $37^{\circ} \mathrm{C}$ for $24 \mathrm{hrs}$. Extracts treatment Media was discarded. Plates were washed with Phosphate buffer saline PBS and fixed using 10\% formalin (BDH-England) as $0.1 \mathrm{ml} /$ well for 2 hrs at room temperature according to Jerry et al., (1990). Fixative was discarded and the plates were stained using $0.3 \%$ crystal violet (Sigma-Aldrich-USA) for 30 minutes at room temperature. Excess dye was removed by water flushing. Stained residual living cells were distained using ethanol-glacial acetic acid (BDH-England), 50\% $(\mathrm{V} / \mathrm{V})$ as $0.05 \mathrm{ml} /$ well for 1 minute. Optical density (O.D) was measured using ELISA reader at wave length of $550-570 \mathrm{~nm}$. The mean optical densities of test and control wells were recorded. Viability percentage was determined according to (Ho-Joon et al., 2000) as follows:

Number of residual living cells $=$

(O.D of treated cells/ O.D of untreated cells) X Number of negative control cells $\left(10^{4}\right.$ cells $\left./ 0.1 \mathrm{ml}\right)$. 
(Number of residual living cells / Number of negative control cells) X 100 .

\section{3- Exposure facility:}

Square Amplitude Modulated Waves (QAMW), generated from two generators. The carrier was 10 $\mathrm{MHz}$ sine wave with amplitude $\pm 10 \mathrm{Vpp}$ generated from a synthesized arbitrary wave form generator type Thurbly Thander Instruments (TTi TGA 1230) manufactured by Huntingdon Cams England .This wave was square Amplitude Modulated (AM) by a second wave generator model AFG 310 manufactured by Sony Tectonics, Japan with a modulation depth of \pm 1 Vpp. For viral samples exposure, the suspension of the sample $(50 \mu \mathrm{L}$ RVFV/ $2 \mathrm{~mL}$ Vero cells) was exposed to QAMW from the generators through the use of two parallel plate electrodes placed on the outer surface of the cuvettes. The samples were exposed to different modulating frequencies in the range $(1-10 \mathrm{~Hz})$ with step of $1 \mathrm{~Hz}$ for $30 \mathrm{~min}$ each, to find out the enhancing and inhibiting frequency of the viral growth as in figure (1).

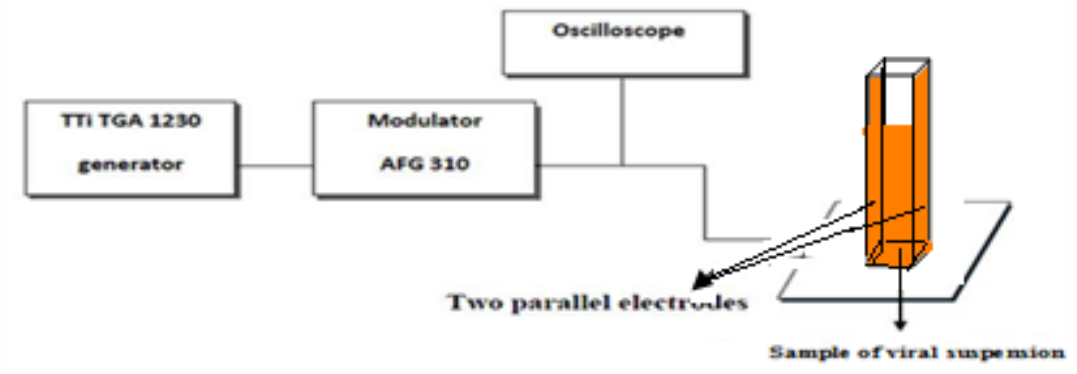

Figure (1): Circuit block diagram of the exposure facility of the viral sample.

4-Determination of the cytotoxicity (RVFV on Vero cells) and the morphological evaluation after the exposure to Electromagnetic field:

Vero cells $(100 \mu /$ well) were plated into 96-well cell culture 199 medium with $10 \%$ fetal bovine serum, $1 \%$ sodium pyruvate and $1 \%$ penicillin- streptomycin . The culture medium and RVFV on Vero cells after were exposed to different modulated square wave frequency of the ELF of the AM modulated electric fields. Control samples were measured in parallel with exposed ones. Each experiment was made in triplicates. There were renewed every 2 days. On day 6 cell numbers were determined with an inverted microscope by counting viable cells and dead cells. Collected samples were 10 fold serially diluted $10^{-1}-10^{-8}$ for determination of residual living virus titer. Growth medium was discarded from previously prepared cell culture 96- well plates (Dynatech, Alexandria, VA, USA), $0.1 \mathrm{ml}$ of each dilution was dispensed to 4 wells- un-inoculated cell control was considered. Infected plates were sealed and kept at $37^{\circ} \mathrm{C}$ at $5.2 \% \mathrm{CO}_{2}$ concentration for 7 days with daily microscopic observation using inverted microscope (Nikon-Japan) for detection of cellular changes. Also, the collected samples were titrated using suckling mice families 1-3 days old. Residual live RVFV titer in each treatment was determined according to (Reed and Muench, 1938). The mean RVFV infectivity titer depletion / hr were determined.

\section{[ B ] In vivo studies:}

\section{1- Animals and experimental design:}

Fourty eight males Balb/c mice, of average weight $(20+2)$ gm each, were housed under condition of fixed temperature $27{ }^{\circ} \mathrm{C}$ and 12 hours of light per day at the animal house of National Cancer Institute (NCI), Cairo, Egypt. Mice were fed on pelted chew composed of $11.2 \%$ moisture, $25.4 \%$ protein, $4.8 \%$ crude fibers, $8.5 \%$ ash, and $3.4 \%$ fat and acidified tap water was supplied ad libitum. Cellulose (1\%), test protein-casein (10\%), sugar (7\%), and corn starch added to make up to $100 \%$. Food and water were given ad labium. The animals were divided into six groups $\mathrm{A}_{1}, \mathrm{~A}_{2}, \mathrm{~A}_{3}, \mathrm{~A}_{4}, \mathrm{~A}_{5}$ and the negative control.

$A_{1}, A_{4} \& A_{5}$ animals were infected by injection intraperitoneal (i.p) with dose of RVFV $(0.15$ $\mathrm{mg} / \mathrm{Kg}$ body weight (b.w)) and left for survival. $\mathrm{A}_{4} \& \mathrm{~A}_{5}$ were exposed for 30 minutes /day along four successive days to $4.4 \mathrm{~Hz} \& 5.2 \mathrm{~Hz}$ respectively while $\mathrm{A}_{1}$ without treatment any further treatment and left for survival . $\mathrm{A}_{2} \& \mathrm{~A}_{3}$ animals were exposed to $4.4 \mathrm{~Hz} \& 5.2 \mathrm{~Hz}$ respectively for 30 minutes /day along four successive days, and left for survival control group were injected $100 \mu 1$ of saline by (i.p) and left for survival. 
2-Whole body Exposure facility for the animals.

The output of the second generator that carries QAMW was connected to two parallel copper mesh electrodes of separation distance $1.5 \mathrm{~cm}$ and area $180 \mathrm{~cm}^{2}$. During the whole body exposure the animals were housed between the parallel capacitance electrodes .

\section{3-Laboratory evaluation:}

Blood samples were collected from all the groups weekly (28 days) post immunization. Two samples were collected post injection to determine the level liver enzymes (Mohamed et al 1996). Liver enzymes (SGPT and SGOT) were measured using ALCYON $3000 \mathrm{i}$ analyzer, Abbott laboratories, USA/Canada. Spinreact kits (Ctra, Santa Coloma, Espana) were used in the measurement of ALT and AST according to the method described by (Bergmeyer et al., 1978).

\section{4- Cytokine determination (IFN- $\gamma$ and IL-5):}

The amounts of IFN- $\gamma$ and IL-5 in mouse sera were determined using sandwich enzyme linked immune sorbent assay (ELISA) as described by (Beyaert and fiers, 1998).

\section{5-Histopathological examinations:}

At the end of the experiment all mice were sacrificed, liver samples were excised from the experimental animals of each group and placed in 10\% neutral formalin for $48 \mathrm{hrs}$. They were then processed for paraffin. The sections were taken at $5 \mu \mathrm{m}$ thickness using microtome, processed in alcohol-xylene series and stained with alum-haematoxylin and eosin. The sections were examined microscopically for the evaluation of histopathological changes (Bancroft and Gamble,2002).

\section{6- Survival percentage of the animals for each group: Survival percentage $=$ \\ After exposure survived animals - Pre exposure survived animals x 100 Pre exposure survived animals}

\section{7- Statistical analysis:}

The data collected from repeated experiments, conducted at the same conditions at different times, were pooled. All the results are presented as the difference between stimulated groups and the control groups. For each mice group, the mean comparisons among different groups were performed by one-way analysis of variance (ANOVA) or Student T-test. A $P$ value of less than 0.05 was considered statistically significant.

\section{[ A ] In vitro studies:}

\section{Results}

\section{1- Effects of exposure to Electric Field (QAMW) on RVFV growth and Vero cells:}

RVFV suspensions were exposed for a duration time of 30 minutes of the virus on its growth characteristics studied to different frequencies of square amplitude modulated waves (QAMW) in the range of $1-10 \mathrm{~Hz}$ to determine the resonance frequency of growth inhibition and enhancement then the TCID ${ }_{50}$ of the samples was measured. Then different groups of RVFV suspension were exposed to QAMW at resonance frequency of growth inhibition and enhancement for period of 30 minutes in order to determine the optimum exposure period and according to treatment schedule of once/day were used in the experiments and wave emission continuous and the growth characteristics for control and exposed groups were studied.

The results of exposure of RVFV and Vero cells to QAMW for 30 minutes at frequencies (1 to $10 \mathrm{~Hz}$ ), the data indicate a non significant variation of in the activity of the RVFV and Vero cells after exposure to (1 to $10 \mathrm{~Hz}$ ) QAMW for 30 minutes when compared to RVFV and Vero cells non exposed

\section{2- Effects of exposures to electric field (QAMW ) on RVFV injected with Vero cells:}

The data in the figure (2) indicate a highly significant growth enhancement occurred in RVFV injected with Vero cells after exposure to $4.4 \mathrm{~Hz}$ QAMW for 30 minutes $(P \leq 0.001)$.In contrast, The data in the figure indicate a highly significant growth inhibition occurred in RVFV injected with Vero cells after exposure to 5.2 $\mathrm{Hz}$ QAMW for 30 minutes $(P \leq 0.002)$ when compared to RVFV injected with Vero cells non exposed. These results reflect that the QAMW $4.4 \& 5.2 \mathrm{~Hz}$ respectively is the resonance frequency of growth enhancement and inhibition for RVFV. 


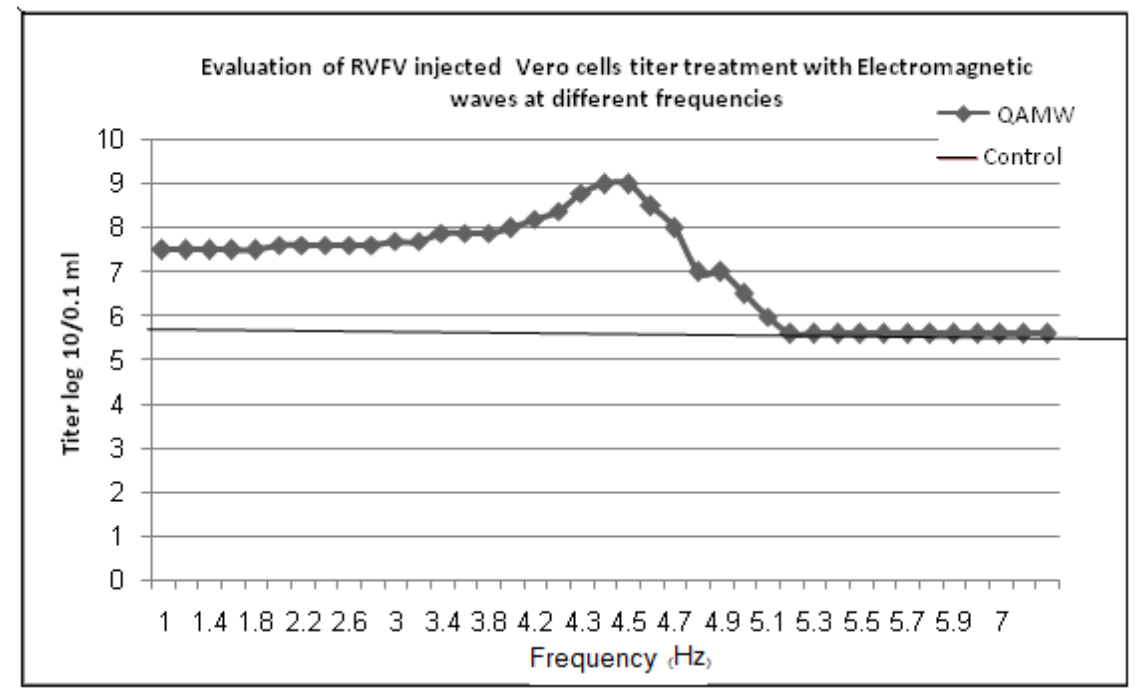

Figure (2): The variation of the RVFV and Vero cells exposed for 30 minutes to QAMW at different frequencies showing the enhancement and inhibition at $4.4 \& 5.2 \mathrm{~Hz}$ respectively. The data are expressed as mean \pm S.E.

\section{[ B ] In vivo studies:}

The two injected mice groups (The exposed and a non exposed mouse to QAMW at frequencies 4.4 or $5.2 \mathrm{~Hz}$ ) were treated according to the experimental schedule for 30 minutes once/day and used in the experiments with wave emission continuous. Biochemical tests were determined by evaluating various cellular activities (SGPT\&SGOT) and level cytokines production (IFN- $\gamma$ and IL-5) in serum.

\section{1- Effects of continuous exposure to QAMW on RVFV injected with Vero cells on level SGPT\&SGOT profile :}

As shown in Fig. (3), the data exhibited the similarities or differences between the non exposed (control group) and the exposed $\mathrm{A}_{1}, \mathrm{~A}_{2}, \mathrm{~A}_{3}, \mathrm{~A}_{4}, \& \mathrm{~A}_{5}$ groups. Figure (3) illustrated the variation between the control group and $\mathrm{A}_{1}, \mathrm{~A}_{2} \& \mathrm{~A}_{3}$ groups and showed a highly significant increase in the serum level of SGPT\&SGOT $\left(P \leq 0.02, P \leq 0.01\right.$ and $P \leq 0.03$ respectively) but less than $\mathrm{A}_{4} \& \mathrm{~A}_{5}$ groups $(P \leq 0.001$ and $P \leq$ 0.002 respectively).

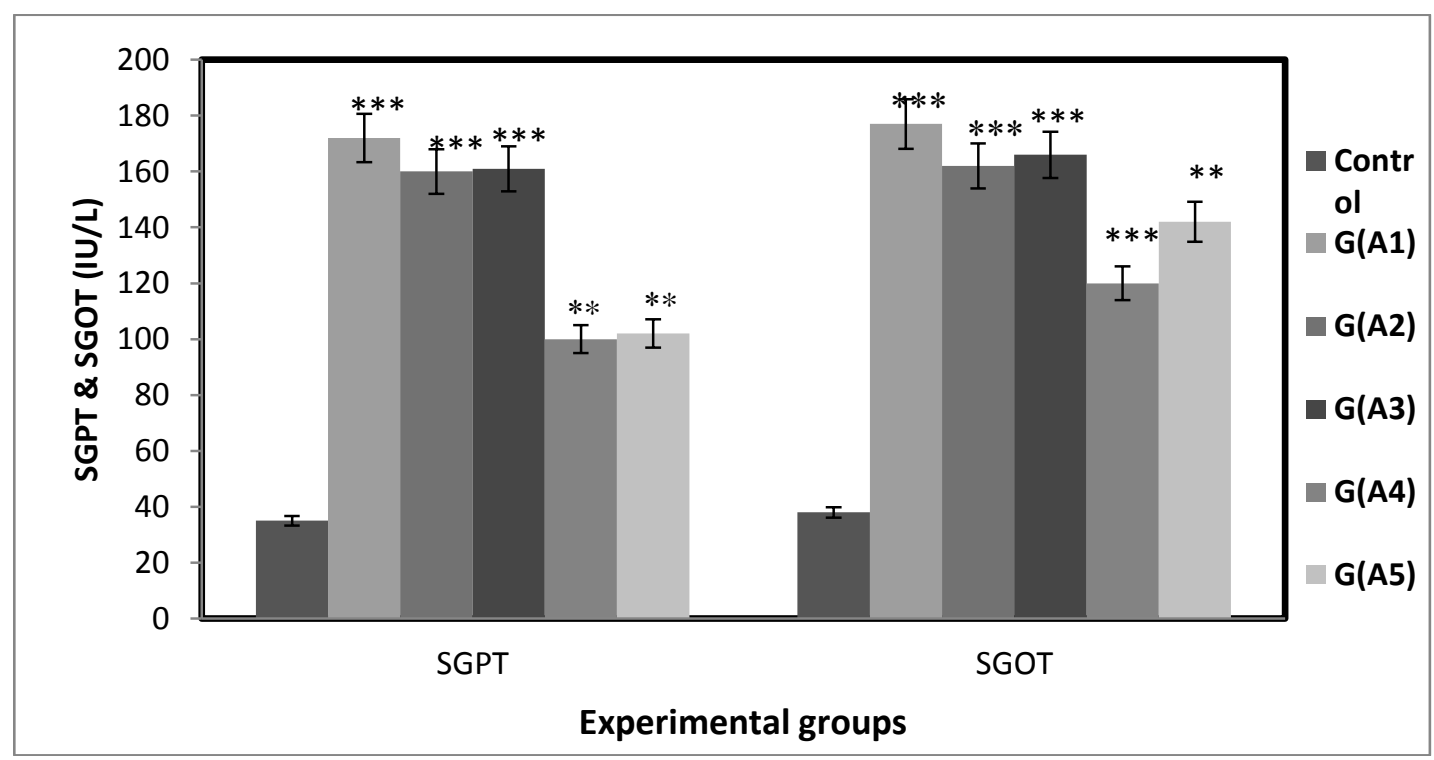

Figure (3): Level of SGPT \& SGOT in serum of mice in exposed cells and non exposed cells to QAMW. The data are expressed as mean \pm S.E. $* * P \leq 0.01$, *** $P \leq 0.001$ 
2- Effects of continuous exposure to QAMW on RVFV injected with vero cells on level production of IFN$\gamma$ and IL-5 profile :

Figure 4 illustrated the variation between control group and groups $A_{1}, A_{2} \& A_{3} A_{4} \& A_{5}$. The serum level of IFN- $\gamma$ of groups $\mathrm{A}_{2} \& \mathrm{~A}_{3}$ showed a significant increase in the serum level of IFN- $\gamma(P \leq 0.05$ and $P \leq$ 0.05 respectively). While, the serum level of IFN- $\gamma$ of groups $\mathrm{A}_{1}, \mathrm{~A}_{4}$ and $\mathrm{A}_{5}$ exhibited a significant decrease $(P$ $\leq 0.02, P \leq 0.01$ and $P \leq 0.03$ respectively). Figure 5 illustrated the variation between control group and groups $A_{1}, A_{2}, A_{3} A_{4} \& A_{5}$. Where the results showed slightly increase but non-significant in level of IL-5 production in serum in groups $A_{2}$ and $A_{3}$. While the level of IL-5 of group $A_{1}$ showed a highly significant suppression more than in the groups $\mathrm{A}_{4} \& \mathrm{~A}_{5}(P \leq 0.001, \mathrm{P} \leq 0.01$ and $P \leq 0.01$ respectively) when compared to control.

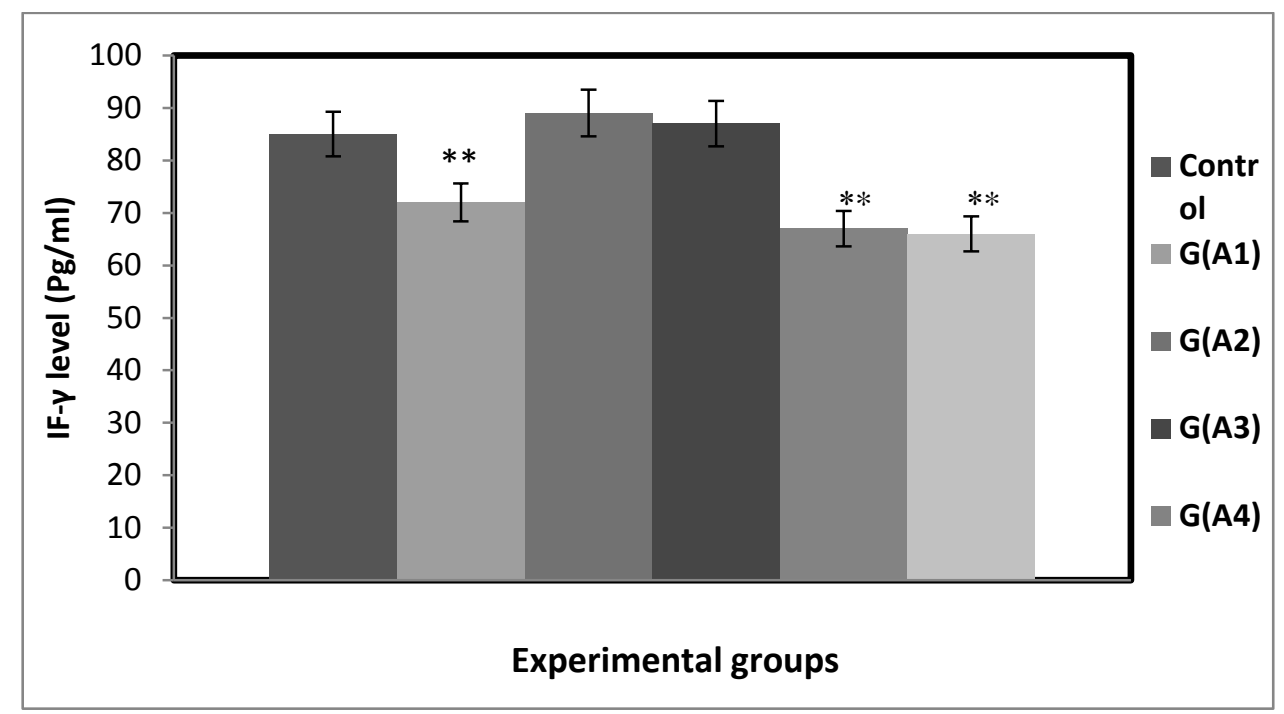

Figure (4): Level of IFN- $\gamma$ production in serum of mice in exposed cells and non- exposed cells to QAMW. The data are expressed as mean \pm S.E. ** $P \leq 0.01$

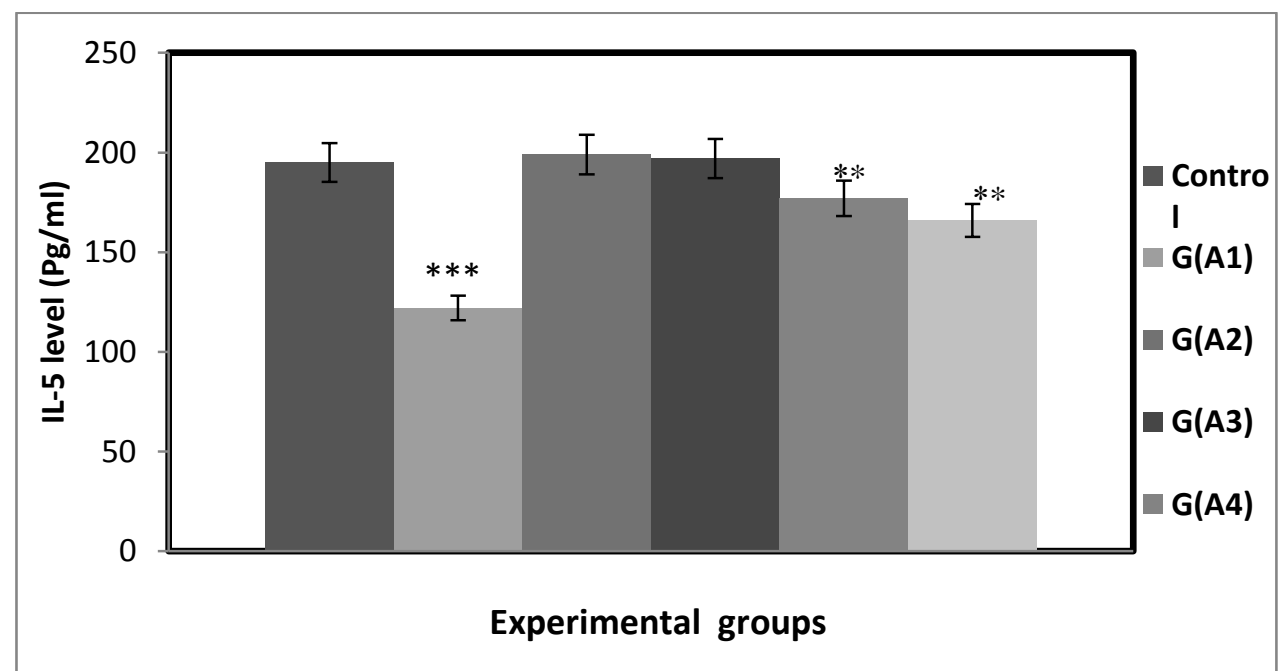

Figure (5): Level of IL-5 production in serum of mice in exposed cells and non exposed cells to QAMW. The data are expressed as mean \pm S.E. $* * P \leq 0.01$, *** $P \leq 0.001$

\section{3- The percentage of survival rate:}

In the group $A_{1}$, the animals which injected with dose of RVFV in $500 \mu 1$ of RPMI medium $(0.15 \mu \mathrm{g} / \mathrm{kg}$ b. wt (i.p) only began to die in the 10 days post injection, In group $A_{2}$, the animals which exposed its whole body into ELF at $4.4 \mathrm{HZ}$, began to die in the 16 days. While the animals of group $\mathrm{A}_{3}$ which exposed its whole body into ELF at $5.2 \mathrm{~Hz}$, began to die in the 19 days. The animals of group $\mathrm{A}_{4}$ that injected with dose of RVFV in 500 $\mu \mathrm{l}$ of RPMI medium $(0.15 \mu \mathrm{g} / \mathrm{kg}$ b. wt (i.p), exposed its whole body into ELF at $4.4 \mathrm{~Hz}$ remained more than 12 days but groups $A_{5}$ that injected with dose of RVFV in $500 \mu \mathrm{l}$ of RPMI medium $(0.15 \mu \mathrm{g} / \mathrm{kg} \mathrm{b}$. wt (i.p) and exposed whole body into ELF at $5.2 \mathrm{~Hz}$ remained more than 25 days .. It seems interesting to find that more than $30 \%$ of the animals of group $A_{5}$ that injected with dose of RVFV in $500 \mu$ of RPMI medium $(0.15 \mu \mathrm{g} / \mathrm{kg}$ 
b. wt (i.p ) and exposed its whole body into ELF at 4.4 or $5.2 \mathrm{~Hz}$ remained more than 20 days. This result indicated that there are positive effects of the QAMW on both of RVFV growth and survival period of the animals.

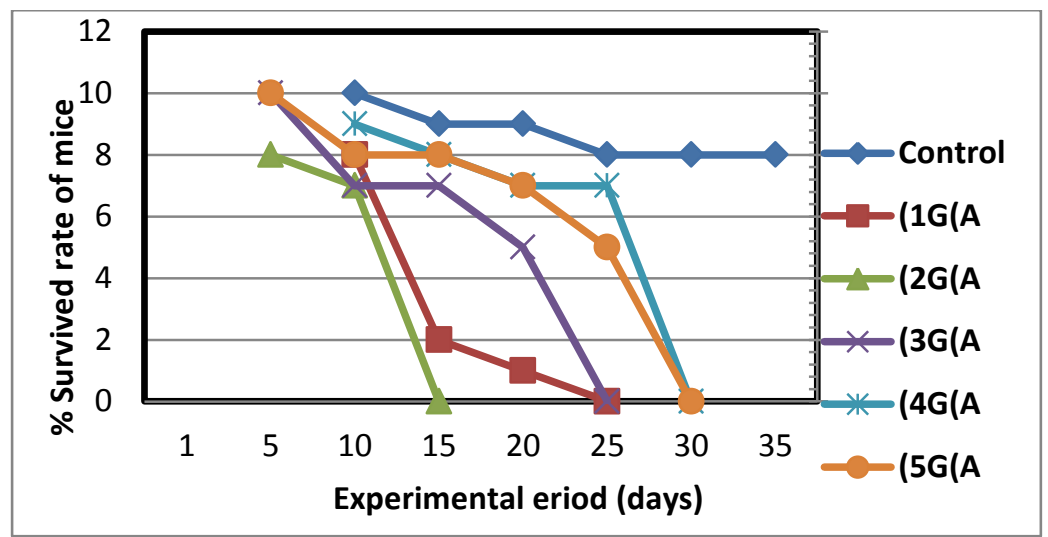

Figure (6): Variation of the survival rate percentage as a function of the incubation period for animals from control, $A_{1}, A_{2}, A_{3}, A_{4} \& A_{5}$, groups. The data are expressed as mean \pm S.E.

\section{4- Effects of continuous exposure to QAMW on RVFV injected with Vero cells on histopathological findings:}

Figure (7): Structure of liver tissue in control group (A) mice showing central vein and intact hepatocytes. However, liver section of group $\left(\mathrm{A}_{1}\right)$ where the animals were injected with RVFV and non-exposed QAMW displayed dilatation and congestion in the central and portal veins associated with cystic bile duct and inflammatory cells infiltration in the portal area (Fig. 8). While the animals exposing RVFV to QAMW prior to i.p. Injection (Group $\mathrm{A}_{2}$ ) exhibited granular and vacuolar degenerations in the hepatocytes (Fig.9). In addition, the group $\mathrm{A}_{3}$ showing a marked dilation, granular and vacuolar degenerations in the hepatocytes (Fig. 10). In group $\mathrm{A}_{4}$, the central and portal veins showed dilatation, congestion associated with inflammatory cells infiltration in the portal area and degeneration in the hepatocytes (Fig.11). The hepatocytes of group $\mathrm{A}_{5}$ exhibited granular and vacuolar degenerations (Fig.12).

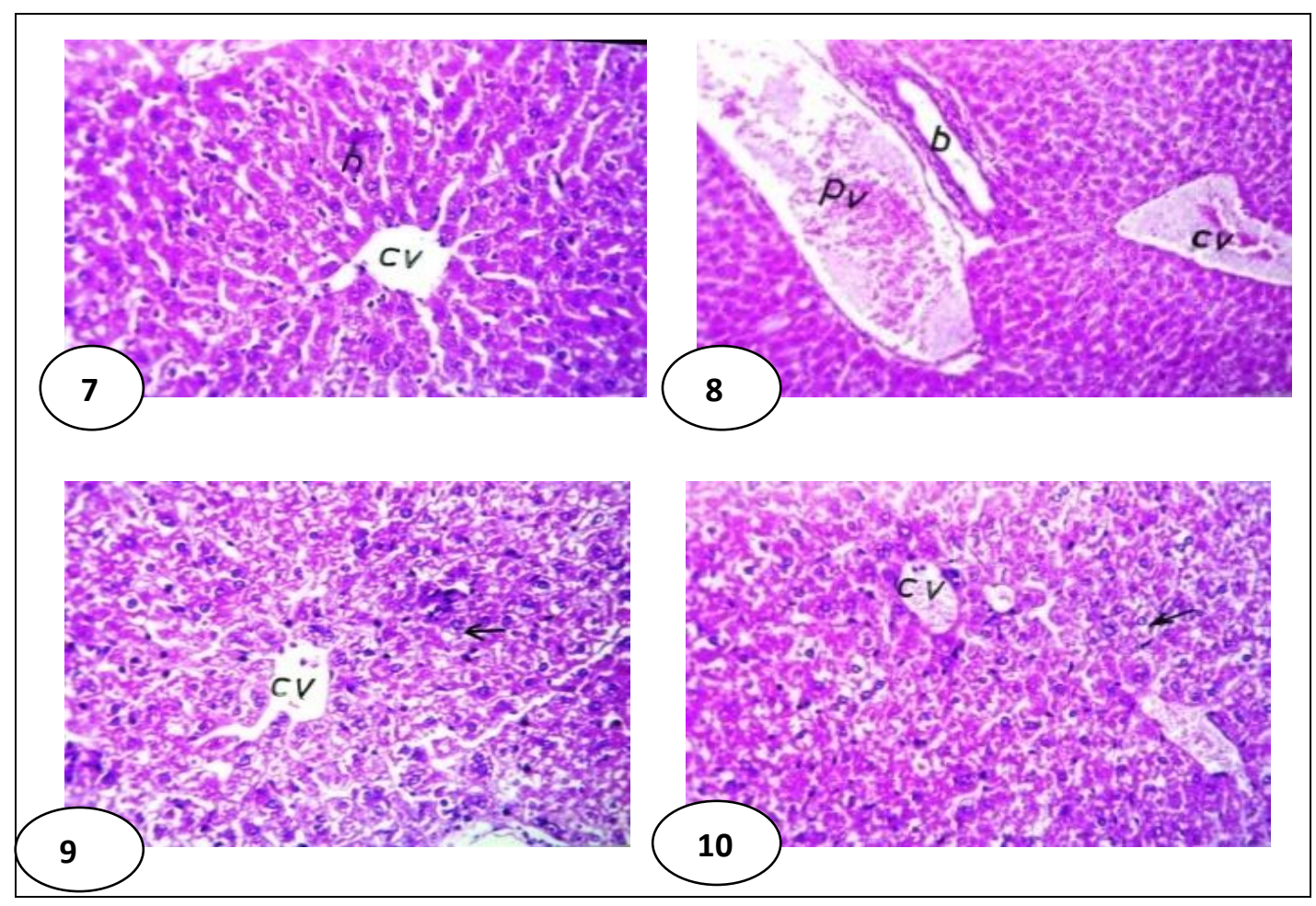




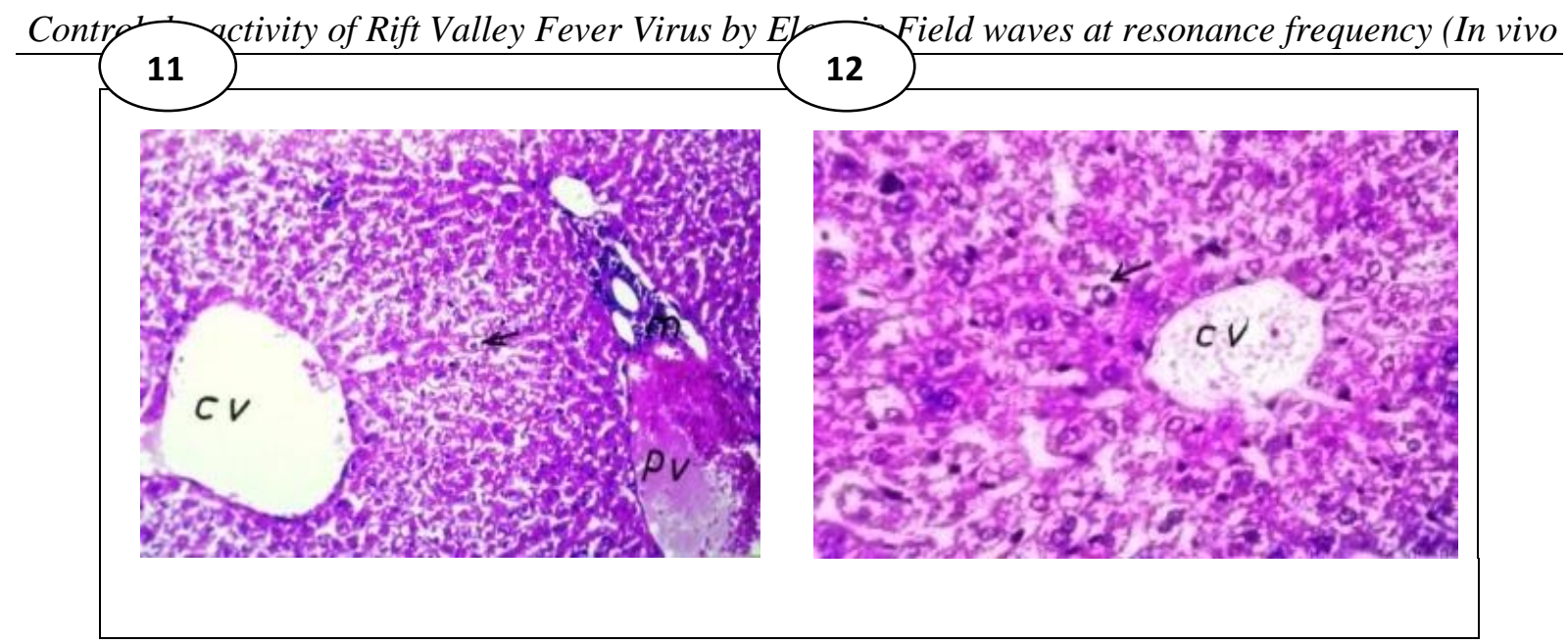

Figure (7): Photomicrograph of liver tissue of control mice liver exhibiting hepatic lobules, central veins (CV), from which hepatocytes are radiated and portal spaces around lobules, (H\&E, X:200).

Figure (8): In the group $A_{1}$, the cells around central vein (CV) appeared abnormal, the cells around portal spaces and boundaries of hepatic lobules have vacuolated cytoplasm $(\mathrm{V})$ with nuclear condensation (C), (H\&E, X:200).

Figure (9): In the group $A_{2}$, granular and vacuolar degenerations were observed in many hepatic lobules close to central vein $(\mathrm{CV}),(\mathrm{H} \& \mathrm{E}, \mathrm{X}: 200)$.

Figure (10): In the group $A_{3}$, it showed a decrease marked dilation and granular and vacuolar degenerations in the hepatocytes with enlarged nuclei. (H\&E, $X: 200)$.

Figure (11): In the group $A_{4}$ the central and portal veins showed dilatation and congestion associated with inflammatory cells infiltration in the portal area and degeneration in the hepatocytes at a distance of central vein $(\mathrm{CV}) .(\mathrm{H} \& \mathrm{E}, \mathrm{X}: 100)$.

Figure (12): In the group $A_{5}$, the hepatocytes displayed a few area of granular and vacuolar degenerations with almost normal appearance of hepatic structure details, (H\&E, X:200).

\section{Discussion}

In the present work, we studied the effect of Extremely low frequency (ELF) electric fields on the growth of RVFV injected with Vero cells .The data present in this work a analyze, the following basic mechanism of interaction of ELF waves with biological system will be discussed based on the biomagnetic resonance model suggested by Fadel, (1998) who reported that since the bioelectric impulses generated from physiological mechanisms have amplitudes in the range of mill volts, electromagnetic waves with amplitudes higher than such biopotentials will be capable to affect the running responsible physiological function.

Pothakamury et al (1996) illustrated that QAMW pulses were more lethal than exponentially decaying pulses. It is well known also that bioelectric signals generated during metabolic activities of cells are in the extremely low frequency range (Patton et al. 1989), therefore, to interfere with these signals; the applied electromagnetic wave should have the same frequency of the bioelectric signal. Since the electrical impedance of tissues ( $\mathrm{X} \mathrm{c}=1 /(2 \pi \mathrm{fc})$ ) is inversely frequency (f) dependent, and will be equal to infinity for direct current (D.C) so, it was necessary to use amplitude modulated waves, with wave carrier of higher frequency to have lower tissue impedance for the applied electromagnetic wave. In this work, a wave carrier of $10 \mathrm{MHz}$ was used. The results indicated that the RVFV has two resonance frequencies with the bioelectric signals generated during cellular division, these frequencies are at $(4.4 \& 5.2 \mathrm{~Hz})$ as was shown in figure (2).

The first frequency effect is enhanced the cellular division and the later is inhibited.

In one part of the present work (in vitro studies) the effect of ELF waves at different frequencies generated from either interferential waves on RVFV, There is no remarkable change of each of the RVFV and the Vero cells alone at a beat frequencies of (1 to 10) Hz. Moreover, the results indicated that the RVFV injected with Vero cells has one resonance frequency with the bioelectric signals generated during cellular division this frequency is at $4.4 \& 5.2 \mathrm{~Hz}$ respectively. The enhancing and inhibiting frequency effect on Vero cell line was observed with remarkable enhancement and inhibition growth for RVFV after exposure to electromagnetic field when compared to RVFV injected with Vero cells none exposed. This reflects that QAMW of Vpp 1 volt (a field of $1 \mathrm{~V} / \mathrm{cm}$ ) at the $4.4 \& 5.2 \mathrm{~Hz}$ respectively are the resonance frequency of growth enhancement and inhibition for RVFV. The present findings indicated that the exposure of the microorganism RVFV for 30 minutes to $5.2 \mathrm{~Hz}$ QAMW of Vpp 1 volt (a field of $1 \mathrm{~V} / \mathrm{cm}$ ) inhibited the activity of the microorganism to be less than the control by $30 \%$. On the other hand exposure to the same waves at $4.4 \mathrm{~Hz}$ enhanced cellular division of the microorganism by $20 \%$. 
In the current work (in vivo studies) the mice were i.p. injected RVFV groups. Biochemical test was determined by evaluating various cellular (SGPT\&SGOT) and cytokines (IFN- $\gamma$ and IL-5). In addition to that, its effects on histopathological findings of liver in different experimental groups. The data exhibited that the production level of both of IFN- $\gamma$ and IL-5 in serum showed a slightly increase in their levels in the groups $\mathrm{A}_{2}$ and $A_{3}$ but not significance. While in the groups $A_{1}, A_{4}$ and $A_{5}$ induced a highly significant suppress in each of IFN- $\gamma$ and IL-5 production, but in group $\mathrm{A}_{1}$ exhibited more suppression than groups $\mathrm{A}_{4}$ and $\mathrm{A}_{5}$ when compared with control group.The biochemical tests (SGPT\&SGOT) of groups $A_{1}, A_{2}, A_{3}, A_{4}, A_{5}$, and control were determined. The data recorded a highly significant increase in the enzymatic activity (SGPT) starting with groups $A_{1}, A_{2}$ and $A_{3}$ followed by decreasing gradually in groups $A_{4}$ and $A_{5}$, but, still increasing in its level production when compared to control group. Moreover, the enzymatic activity (SGOT) of groups $A_{1}, A_{2}, A_{3}, A_{4}$, $\mathrm{A}_{5}$, and control exhibited also showed the similar effects of SGPT. These changes of enzymaties activities (SGPT\&SGOT) accompanied by histopathological findings in the liver of different experimental groups .

The survival rate of mice used in vivo study has been decreased. It also indicated the progressive growth in RVFV with incubation time, and no animal survived at day 40 PI Fadel et al (2010). The results showed that animals of control group exhibited no animals lived longer than 40 days. In group $\mathrm{A}_{1}$ animals which injected with dose of RVFV (i.p) only began to die 10 days post injection, the animals of groups $\mathrm{A}_{2}$ which exposed whole body into ELF at $(4.4 \mathrm{~Hz})$ began to die 16 days while the animals of groups $\mathrm{A}_{3}$ which exposed whole body into ELF at $(5.2 \mathrm{~Hz})$ began to die 19 days. Groups $\mathrm{A}_{4}$ that injected with dose of RVFV (i.p) and exposed whole body into ELF at $(4.4 \mathrm{~Hz})$ remained more than 12 days but groups $\mathrm{A}_{5}$ that injected with dose of RVFV (i.p) and exposed whole body into ELF at $(5.2 \mathrm{~Hz})$ remained more than 25 days. It seems interesting to find that more than $30 \%$ of the animals of group $A_{5}$ that injected with dose of RVFV (i.p ) and exposed whole body into ELF at $(4.4 \& 5.2 \mathrm{~Hz})$ remained more than 20 days which indicate that there is positive effects of the QAMW on both RVFV growth and survival period of the animals. These findings indicated that the exposed RVFV controlled the QAMW and prevented its expansion other healthy tissues so the treatment of the exposed RVFV to $(5.2 \mathrm{~Hz})$ in-vitro has similar effects as in-vivo.

Most of the experimental work found in the literature used electromagnetic fields of high field intensity in the range from $10 \mathrm{KV} / \mathrm{cm}$ up to several $\mathrm{MV} / \mathrm{m}$ with the aid of very high temperature for inactivation of bacterial growth (Jeantet et al., 1999; Cserhalmi et al., 2002; Fojt et al., 2004; Amiali et al., 2007; Jaegu et al., 2008; Ji et al., 2009; Ruiz-Gomez et al., 2010). These conditions hampered the application of this experimental work in practice either for the treatment of human infections. In contrast, the findings in the present work seem interesting from the point of view that the extremely low frequency electromagnetic waves (ELF-EM) used to deteriorate and inhibit the viral growth of RVFV at (5.2 Hz) QAMW is of low field strength $(200 \mathrm{~V} / \mathrm{m})$ as well as the process of inhibition occurred at $37^{\circ} \mathrm{C}$ which make this new technique can be applicable in many fields.

In a previous study on the effect of extremely low frequency electromagnetic fields on the Rift valley fever virus done by Fadel et al (2013) showed that there is an inhibiting effect for cell multiplication of Rift valley virus at 5.2 Hz QAMW. The inhibiting effect at $5.2 \mathrm{~Hz}$ QAMW may be due to destructive interference of the applied wave with the bio-waves generated during cell multiplication.

To get a better insight into the interaction mechanism of the electromagnetic field with the biological systems the understanding of the bioelectrical signals resulting from the biological system during metabolic activity is required. Mohamed et al. reported that the bioelectrical signals from the microorganism were normally carried out through bending of their cellular membranes which generate an electric impulse through phenomena known as flux electricity. The amplitude and the frequency of these impulses depend on the magnitude and frequency of bending. These impulses travel through the medium separating the microorganisms and are received by the signal receptors at the surface and that impeded the cell membrane. Therefore, the flexibility of the membrane is the most important parameter for generation of these signals. There is also mentioned that the bio magnetic field from the biological system associated to the bioelectrical signals from the membrane of the cells through its metabolic function is very weak in nano Gauss range $\left(20 \times 10^{-8} \mathrm{G}\right)$. When the biological systems exposed to an external magnetic field whose strength is very large relative to the bio magnetic field of the cells, a disturbance in their metabolic function will be expected which leads to death of the cells or increases their cell division, Fadel et al. and Shin-Ichiro et al..

\section{Conclusion}

The present study demonstrated that the inhibiting resonance frequency of ELF-EM waves that deteriorates RVFV growth will be promising method for the treatment of RVFV infection either in vivo or in vitro. This technique is non destructive, non expensive, safe and fast, where only 30 min are needed for the exposure of viral to stop its ability to make cell division and cause changes in its cytokines .Treatment of injected mice by RVFV with $5.2 \mathrm{~Hz}$ seems successful and applicable. 


\section{REFERENCES}

[1]. Amiali M., Ngadi M., Smith J. and Raghavan V.(2007)" Synergistic effect of temperature and pulsed electric field on inactivation of Escherichia coli O157:H7 and Salmonella enteritidis in liquid egg yolk." J. Food Eng. 79: 689-694.

[2]. Arthur RR, (2000): Rift Valley fever. In: Hunter's tropical medicine and emerging disease, 8th ed. Philadelphia: WB Saunders: p253-5.

[3]. Balkhy. Hanan H., Ziad A. Memish. (2003): Rift Valley fever: an uninvited zoonosis in the Arabian peninsula. International Journal of Antimicrobial 21: p153 - 157.

[4]. Bancroft J, D, and Gamble M, (2002)."Theory and Practice of Histological Technique" (5 ${ }^{\text {th }}$ Ed.). Churchill Livingstone, Edinburg and London.

[5]. Bergmeyer, H.; Schreiber, P. and Wahlefeld, A. (1978): Optimization of methods for aspartate aminotransferase and alanine aminotransferase. Clin. Chem. 24 (1): 58-73.

[6]. Beyaert R.and Fiers W. (1998): Tumor Necrosis Factor and Lymphotoxin. In Cytokines. A. R. M.-S. a. R. Thorpe, eds. Academic Press, San Diego, P.335-360.

[7]. Biasin Mara.; Sergio Lo Caputo.; Livianna Speciale.; Fulvia Colombo.; Luigi Racioppi.; Arianna Zagliani.; Claudio Ble.; Francesca Vichi.; Luciano Cianferoni.; Anna Maria

[8]. Blanchard J. and Blackman C. (1994): Bioelectromagnetics. 15: 217-238.

[9]. Bussereau F.; Benejean J. and Saghi N. (1982): Isolation and study of temperature-sensitive mutants of rabies virus. GenVirol.; 60 (pt1):153-8.

[10]. Centers for Disease Control and Prevention CDC (2004): Rift Valley Fever Fact Sheet. Available at http://www.cdc.gov.

[11]. Cohen AD.; Boyer JD.; Weiner DB.; et al., (1998): Modulating the immune response to genetic immunization. FASEB J;12:16111626.

[12]. Cserhalmi Z., Vidacs I., Beczner J. and Czukor B. (2002):" Inactivation of Saccharomyces cerevisiae and Bacillus cereus by pulsed electric fields technology" Innovative food science and emerging technologies. 3:41-45.

[13]. El Hag, M., (2003):"Effect of extremely low frequency electric fields on some biophysical properties and biological activity of some microorganisms", PhD thesis, Faculty of Science, Cairo university.

[14]. Fadel M. A, R. El-Gebaly, A. Aly, A. Sallam, O. Sarhan and H. Eltohamy. (2010):Preventing of Ehrlich tumor metastasis in liver, kidney and spleen by electromagnetic field. International Journal of the Physical Sciences. Vol. 5(12)

[15]. Fadel M. A. (1998) "A New Metabolic Biomagnetic Resonance Model to Describe the Interaction of ELF EM.Fields with Biological Systems" International School on Theoretical Biophysics, Moscoww May.

[16]. Fadel M.Ali, M.A.Ahmed and M.A.El Hag, (2009)."Control of Sclerotium cepivorum (Allium White Rot) activities by electromagnetic waves at resonance frequency". Australian Journal of Basic and Applied Science, 3(3):1994-2000, ISSN 19918178 .

[17]. Fadel, M. Ali, Reem H. Elgebaly, Amany A. Ali, Fakhry F. Ibrahim, (2005). "Control of Ehrlich tumor growth in mice by electromagnetic wave at resonance frequency, in vivo", Electromagnetic biology and medicine, 24: 9-12.

[18]. Filone Claire Marie.; Mark Heise.; Robert W. Doms.; Andrea Bertolotti-Ciarlet (2006): Development and characterization of a Rift Valley fever virus cell-cell fusion assay using alphavirus replicon vectors. Virology, 356:p155-164. Available online atwww.elsevier.com/locate/yviro.

[19]. Finter, N. B. 1990. Dye uptake methods for assessing viral cytopathogenicity and their application to interferon assays. J. gen. virol. 5: 419-427.

[20]. Fleischman G., Ravishankar S. and Balasubramaniam V.(2004)" The inactivation of Listeria monocytogenes by pulsed electric field (PEF) treatment in a static chamber." Food Microbiol. 21: 91-95.

[21]. Flick, R., and Bouloy, M., (2005):. Rift Valley fever virus. Curr. Mol. Med. 5 (8), 827-834.

[22]. Fojt L., Strasak L., Vetterl V. and Smarda J.(2004)" Comparison of the low-frequency magnetic field effects on bacteria Escherichia coli, Leclercia adecarboxylata and Staphylococcus aureus." Bioelectrochemistry $63: 337-34$

[23]. Fox M., Esveld D., Mastwijk H. and Boom R.(2008)" Inactivation of L. plantarum in a PEF microreactor :The effect of pulse width and temperature on the inactivation." Innov. Food Sci. and Emer. Technol. 9: 101-108.

[24]. Ho-Joon, S., Myung, S. C., Suk, Y. J., Hyng, K., and Kyung, I. M. (2000). In vitro cytotoxicity of Acanthamoeb spp. isolated from contact lens containers in Korea by crystal violet staining and LDH release assay. The Korean Journal of Parasitology 38 (2):99102.

[25]. Jaegu C., Douyan W., Takao N., Sunao K., Hidenori A., Xiaofei L., Hiroshi S., Harumichi S., Hitoshi M. and Takeshi S.(2008)" Inactivation of spores using pulsed electric field in a pressurized flow system." J. Appl. Phys. 104: 094701 - 094701-6.

[26]. Jameson Julie.; John Cruz, and Francis A. Ennis. (1998): Human Cytotoxic T-Lymphocyte Repertoire to Influenza A Viruses. J. VIROL, 72 (11): p. 8682-8689.

[27]. Janusz T. Paweska .; Petrus Jansen van Vuren .; Alan Kemp .; Peter Buss.; Roy G. Bengis .; Francis Gakuya.; Robert F. Breiman.; M. Kariuki Njenga and Robert Swanepoel. (2007): Recombinant nucleocapsid-based ELISA for detection of IgG antibody to Rift Valley fever virus in African buffalo. VETMIC, 3797;P 1-8.

[28]. Jayaram S., Castle G. S. And Margaitis, A. (1992): Biotech. Bioeng. 40: 1412-1420.

[29]. Jeantet R., Baron F., Nau F., Rorgnant M. and Brule G. (1999): J. food prot. 62(12): 1381-1386.

[30]. Jerry, L. T., Monika, S. C., and William, J. O. (1990). Synergistic antiviral activity of acyclovir and interferon in human corneal stromal cells. Investigative Ophthalmology \& Visual Science. 30 (3):365-370.

[31]. Ji W., Huang H., Deng A. and Pan C.(2009)" Effects of static magnetic fields on Escherichia coli." Micron. 40: 894-898.

[32]. Lednev V. (1991): Bioelectromagnetics. 12:71-75.

[33]. Liboff A., Rozek R., Sherman M., Mcleod B. And Smith S. (1987): J. Bioelectr. 6:13-22

[34]. Martin O., Qin B., Chang F., Barbosa-Canovas G. and Swason B.(1997) " Inactivation of Escherichia coli in skim milky by high intensity pulsed electric fields" J. Food Proc. Eng. 20: 265-348.

[35]. Masci.; Maria Luisa Villa.; Pasquale Ferrante.; Francesco Mazzotta. and Mario lerici1.(2000): Mucosal and Systemic Immune Activation Is Present in Human imunodeficiency Virus-Exposed Seronegative Women The Journal of Infectious Diseases; 182:p1365-74.

[36]. Mittenzwey , R. Siigmuth , R.and Mei ,W.(1996): Effects of extremely low-frequency electromagnetic fields on bacteria the question of a co-stressing factor. Bioelectrochemistry and Bioenergetics 40:21-27.

[37]. Mohamed F.A.; El-Kaschef A.H.; Reda I.M.; Tantawey H.M. and Hassen R.A. (1996): Biological studies for the importance of Rift Valley Fever Vaccine. ph.D thesis, Suez Canal Univ.Zool. Depart.

[38]. Nicholls, N., (1991): Teleconnections and health In: Teleconnections Linking Worldwide Climate Anomalies (M. H. Glantz, R. W. Katz \& N. Nicholls, eds.), p. 493-510, New York: Cambridge University. 
[39]. Oran AE and Robinson HL. (2003): DNA vaccines, combining form of antigen and method of delivery to raise a spectrum of IFNgamma and IL-4-producing CD4+ and CD8+ T cells. J Immunol.171:p 1999-2005.

[40]. Patton, Harry D., Albert F. Fuchs, Bertil Hille, Akken M. Scher. Robert Steiner. (1989): "Excitable cells and neurophysiology" 21st edition. P 1 - 20 .

[41]. Pothakamury U., Vega H., Zhany Q. Barbosa-Canovas G. and Swanson B. (1996): J.food prot. 59 : 1167 - 1171.

[42]. Saunders R.D., Z.J. Sienkiewicz and C.I. Kowalczuk, (1991) : Biological effects of electromagnetic fields and radiation, J. Radiol. Prot., I 127-42.

[43]. Reed, L. J., and Muench, H. (1938). A simple method of estimating fifty percent endpoints. The American Journal of Hygiene. 27: 493-497.

[44]. Ruiz-Gomez M., Sendra-Portero F. and Martinez-Morillo M.(2010)" Effect of $2.45 \mathrm{mT}$ sinusoidal 50 Hz magnetic field on Saccharomyces cerevisiae strains deficient in DNA strand breaks repair." Int. J. Radiat. Biol. 86: 602-611.

[45]. Shawky, S. (2000): Rift Valley fever.Expedited review. Saudi Medical Journal; 21(12): p1109- 15.

[46]. Swanepoel, R and Coetzer, J.A.W., (2004): Rift Valley fever. In: Coetzer, J.A.W., Tustin, R.C. (Eds.), Infectious diseases of livestock, Vol. 2, 2nd ed. Oxford University Press, Cape Town, Southern Africa, p. 1037-1070.

[47]. Tagourti J., El May A., Aloui A., Chatti A., Aissa R. and Landoulsi A.(2010):" Static magnetic field increases the sensitivity of Salmonella to gentamicin." Ann Microbiol. 60:519-522.

[48]. Van Heather L. Epps.; Masanori Terajima.; Jukka Mustonen.; T. Petteri Arstila.; Elizabeth A. Corey,Antti Vaheri.; and Francis A. Ennis. (2002): Long-lived Memory T lymphocyte Responses after Hantavirus Infection. 196(5), p579-588.

[49]. Vijayan, P. (2004). Antiviral activity of medicinal plants of Nilgiris. Indian Journal of Medical Research. 3 (1):24-27.

[50]. WHO, (2000): Fact Sheet No. 207: Rift Valley Fever.Available at http://www.who.int/mediacentre/factsheets/fs207/en/ [Last Accessed 11/12/05].

[51]. Wouters P., Dutreux N., Smelt J.and Lelieveld H.(1999)" Effects of pulsed electric fields on inactivation kinetics of Listeria innocua". Appl. Environ. Microbiol. 65: 5364-5371.

[52]. Zaki, A.; Coudrier,D.; Yousef, A.I.;. Fakeeh, M.; Bouloy, M.; Billecocq, A. (2006): Production of monoclonal antibodies against Rift Valley fever virus Application for rapid diagnosis tests (virus detection and ELISA) in human sera. Journal of Virological Methods 131: p 34-40.

[53]. Pepperl Sandra.; Gerlinde Benninger.; DO“ ring.; Susanne Modrow.; Hans Wolf. and Wolfgang Jilg. (1998): Immediate-Early Transactivator Rta of Epstein-Barr Virus (EBV) Shows Multiple Epitopes Recognized by EBV-Specific Cytotoxic T Lymphocytes. J. VIROL, 72(11): p. 8644-8649.

[54]. Saunders, R.D. Sienkiewicz Z.J. and Kowalczuk, C.I. (1991):Biological effects of electromagnetic fields and radiation, J. Radiol. Prot., I :127-42.

[55]. Zajac Allan J..; John M. Dye and Daniel G. Quinn. (2003) : Control of Lymphocytic Choriomeningitis Virus Infection in Granzyme B Deficient Mice. Virology, 305: p 1-9.

[56]. Alvarez I., Raso J., Palop A. and Sala F.(2000)" Influence of different factors on the inactivation of Salmonella senftenberg by pulsed electric fields." Int. J. Food Microbiol. 55: 143-146.

[57]. Gowen BB, Holbrook MR.(2008): Animal models of highly pathogenic RNA viral infections: hemorrhagic fever viruses. Antiviral Res. ;78:79-90.

[58]. Moutailler S, Krida G, Schaffner F, Vazeille M, Failloux AB.(2008):Potential vectors of Rift Valley fever virus in the Mediterranean region. Vector Borne Zoonotic Dis. ;8:749-53.

[59]. Turell MJ, Dohm DJ, Mores CN, Terracina L, Wallette DL, Jr, Hribar LJ, Pecor JE, Blow JA. (2008):Potential for North American mosquitoes to transmit Rift Valley fever virus. J Am Mosq Control Assoc. ;24:502-7.

[60]. Turell MJ, Wilson WC, Bennett KE, (2010):Potential for North American mosquitoes (Diptera: Culicidae) to transmit RiftValley fever virus. J Med Entomol 47, 884-889.

[61]. Bouloy M, Flick R.(2009): Reverse genetics technology for Rift Valley fever virus: current and future applications for the development of therapeutics and vaccines. Antiviral Res. ;84:101-18.

[62]. Rebekah Kading, Mary Crabtree, Barry Miller. (2013): Inactivation of infectious virus and serological detection of virus antigen in Rift Valley fever virus-exposed mosquitoes fixed with paraformaldehyde. Journal of Virological Methods Online publication date: 1 -Feb-2013.

[63]. Kortekaas, J.A.F.G. Antonis, J. Kant, R.P.M. Vloet, A. Vogel, N. Oreshkova, S.M. de Boer, B.J. Bosch, R.J.M. Moormann. (2012) Efficacy of three candidate Rift Valley fever vaccines in sheep. Vaccine Online publication date: 1-Mar-2012. 